\title{
Design of Residual Film Recovery Machine for Whole Plastic Film Mulching on Double Ridges
}

\author{
Shilin Zhang ${ }^{a}$, Fei Dai ${ }^{b}$, Wuyun Zhao ${ }^{\text {c, }}$ * \\ College of Mechanical and Electrical Engineering, Gansu Agricultural University, Lanzhou 730070, \\ China. \\ a619647034@qq.com, bdaifei@gsau.edu.cn, c, *: zhaowy@gsau.edu.cn
}

\begin{abstract}
Keywords: whole plastic film mulching on double rides; recycling machine for residual film; finite element analysis.
\end{abstract}

\begin{abstract}
Aiming at the problem of serious pollution caused by waste film in the process of rain collecting, soil moisture and increasing yield, this paper analyzes and studies the characteristics of the whole film double ditch sowing technology in dry land and puts forward a new type of residual film recovery machine for whole plastic film mulching on double rides. The residual film recovery machine is mainly composed of a flip-film device, a film picking device, a film unloading device and a film collecting device. By using Solidworks software, building the three-dimensional modeling and engineering drawings. Making the finite element analysis and optimal design of the flip-film shovel through Solidworks Simulation, and the theoretical analysis and design of the film-collecting drum are made.
\end{abstract}

\section{Preface}

Whole film double ditch sowing technology in dry land has the characteristics of inhibiting evaporation of film, gathering rainwater in ditch, sowing and fertilizing in ditch, and ensuring the quality and yield of crops while effectively improving the utilization rate of water and fertilizer. Because of its remarkable economic effect, since 2003, whole-film double ditch sowing technology in dry land has rapidly been popularized in arid and rainless areas such as Gansu [1]. But the commonly used plastic film is polyethylene hydrocarbon compound, in the natural condition is almost impossible to decompose effectively in short time. This not only greatly reduces the permeability of the soil, but also hinders the transfer of nutrients to plants in the land. Many residual films mainly remain in the $0 \sim 300 \mathrm{~mm}$ deep farmland, accounting for the total residual film volume of $4 / 5$. Longterm residue of waste film in the soil, will form several barrier layers, destroying soil structure, resulting in and serious consequences [2]. At present, the residual film recovery machine in the market is not entirely suitable for the whole film double ditch planting mode, and there are some problems such as complex structure, low pickup rate and lag of the principle of picking up membrane, which can't meet the practical needs of solving the problem of residual membrane pollution in Gansu province [3].

Therefore, in view of the above problems and deficiencies, this paper designs a residual film recovery machine which is suitable for the whole film double ditch planting mode in northwest China. The machine can accomplish the work of picking the film, collecting film and unloading film at a time, can greatly improve the work efficiency, reduce the labor intensity, effectively solve the pollution problems brought by the waste residue film, which have great significance for the regional ecological protection and agricultural sustainable development.

\section{Structure and Working Principle of the Whole Machine.}

\subsection{Machine Structure}

Residual film recovery machine is mainly composed of three-point suspension frame, frame, land wheel, flip film mechanism, film-collecting mechanism, comb-film mechanism, film-collecting roller, film-collecting box and transmission. The flip film mechanism consists of a disk cutting knife, the 
spring and the film-upturning shovel are composed, to cooperate with the whole film double ditch planting mode, the space between the adjacent disk cutting knife and the film-upturning shovel is $400 \mathrm{~mm}$, and the spacing between the middle adjacent disc cutting knife and the film-upturning shovel is $700 \mathrm{~mm}$ [4]. The mechanism is composed of a film-picking roller, a film-picking tooth and a cam disc. The comb-film mechanism consists of a comb-film wheel and a comb-film plate. The transmission mechanism consists of a reversing gear set, a sprocket and a chain. The whole structure is shown in Figure 1.

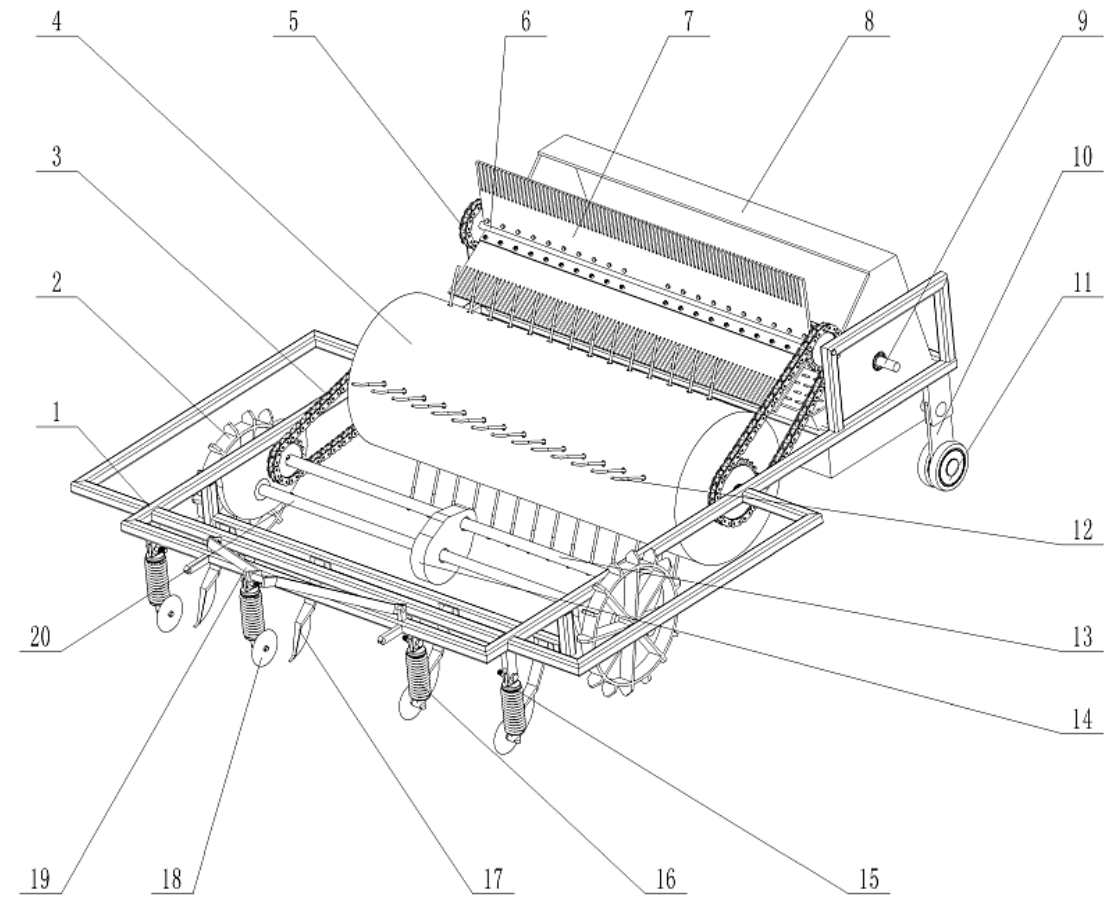

1. Frame 2. Land wheel 3. Chain 4. Film-picking roller 5. Comb-film wheel 6. Comb-film wheel axis 7. Comb-film plate 8. Film-collecting box9. Film-collecting roller 10. Walking wheel bracket 11. Walking wheel 12. Film-picking tooth 13. Sprocket Shaft 14. Reversing gear group 15. Support shaft 16. Profiling spring 17. Film-upturning Shovel 18. Film-cutting Disc 19. Three-point suspension frame 20. Land wheel axle

\subsection{Working Principle}

Fig 1. Structure of residual film recovery machine

When the residual film recovery machine work, the machine can be towed by tractor with power of $20 \mathrm{kw}$, after entering the ground, the waste film which is distributed on the surface is cut by the disk cutting knife, and the waste film under the surface is turned out and the soil is loosened by the film-upturning shovel. Under the driving of the land wheel, the film-collecting roller rotates with it, and the film-picking teeth is rotated along the cam track and realizes the telescopic state. Film-picking teeth pick up the film from the surface of the land, the film rotating to the film-picking roller rear, then the residual film is combed off from the teeth by the comb-film plate [5]. Most of the residual films combed under off by the comb-film plate are twined on the film-collecting roller, and the other part is collected into the film-collecting box to complete the waste film recovery work. The working power of the machine is provided by the land wheel, which is reversed by the reversing gear set on the camshaft, and then transmitted to the film-picking roller by the sprocket wheel. The sprocket on the film roller relates to the sprocket on the comb-film wheel axis, and the sprocket on the comb-film wheel axis relates to the film-collecting roller to complete the power transmission.

\subsection{Technical Parameters}

According to the working speed of the tractor and the film-picking roller, the speed of $3.5 \mathrm{~km} / \mathrm{h} \sim 5.5 \mathrm{~km} / \mathrm{h}[6]$ is determined. By the working width of the machine and its working speed, the productivity per hour is calculated $0.053 \sim 0.083 \mathrm{hm}^{2} / \mathrm{h}$. The technical parameter indicators are shown in table 1. 
Table 1. Main technical parameters

\begin{tabular}{cc}
\hline Name & Parameter \\
\hline Machine size $($ length $\times$ width $\times$ height $) / \mathrm{m}$ & $2.4 \times 2.2 \times 0.96$ \\
Traction mode & Tractor Traction Type \\
Supporting power $/ \mathrm{kw}$ & $15 \sim 30$ \\
The width of $/ \mathrm{m}$ & 1.5 \\
Operating speed $/(\mathrm{km} \cdot \mathrm{h}-1)$ & $3.5 \sim 5.5$ \\
Operating hourly productivity $/\left(\mathrm{km}^{2} \mathrm{~h}-1\right)$ & $0.53 \sim 0.83$ \\
\hline
\end{tabular}

\section{Design of Key Parts of Film Residue Recovery Machine with Full Film Double Ditch}

\subsection{Design and Optimization of the Film-Upturning Shovel}

\subsubsection{The Design of The Film Shovel and the Optimization Scheme}

In the design process, three kinds of design schemes of the film-upturning shovel are proposed. The concrete method is to increase the strength of the film-upturning shovel by increasing the support plate. After the shape, thickness and material of the supporting plate of the film-upturning shovel 2 are improved, the film-upturning shovel 3 is obtained to further improve the strength of the filmupturning shovel and reduce and eliminate the stress concentration. Improvement of the structure of the film-upturning shovel as shown in Fig. 2 (a) is a film-upturning shovel 1, fig 2 (b) is a filmupturning shovel 2, Figure 2 (c) is a film-upturning shovel 3.

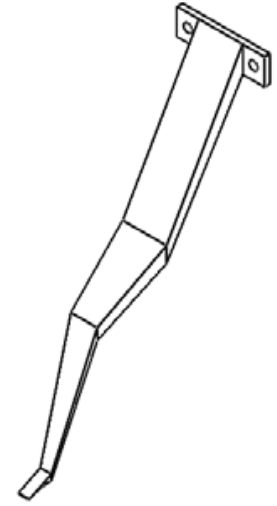

(a)

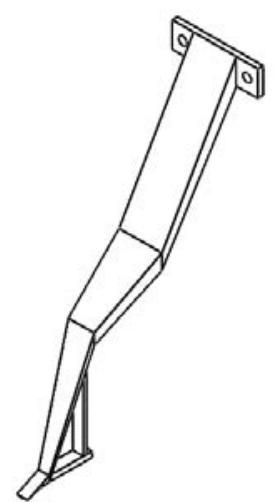

(b)

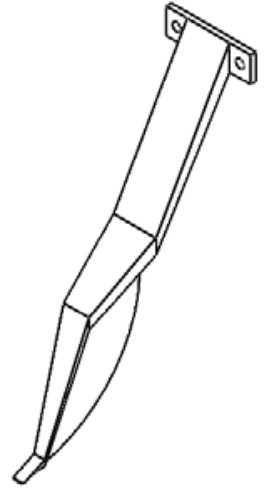

(c)

Fig 2. The structure improvement of the film shovel

\subsubsection{Finite Element Analysis of Simulation Based on Solidworks}

Using SolidWorks three-dimensional software to build a three-dimensional model of the filmupturning shovel, simulate the residual film recovery machine in the work situation, assuming the work of the starting film depth of $50 \mathrm{~mm}$, the f film-upturning shovel resistance is set to $500 \mathrm{~N}$. The finite element analysis of the SolidWorks simulation is carried out on film-upturning shovel [7]. The stress and strain distributions of film-upturning shovel 1, film-upturning shovel 2 and film-upturning shovel 3 were obtained, as shown in (a) and (b).
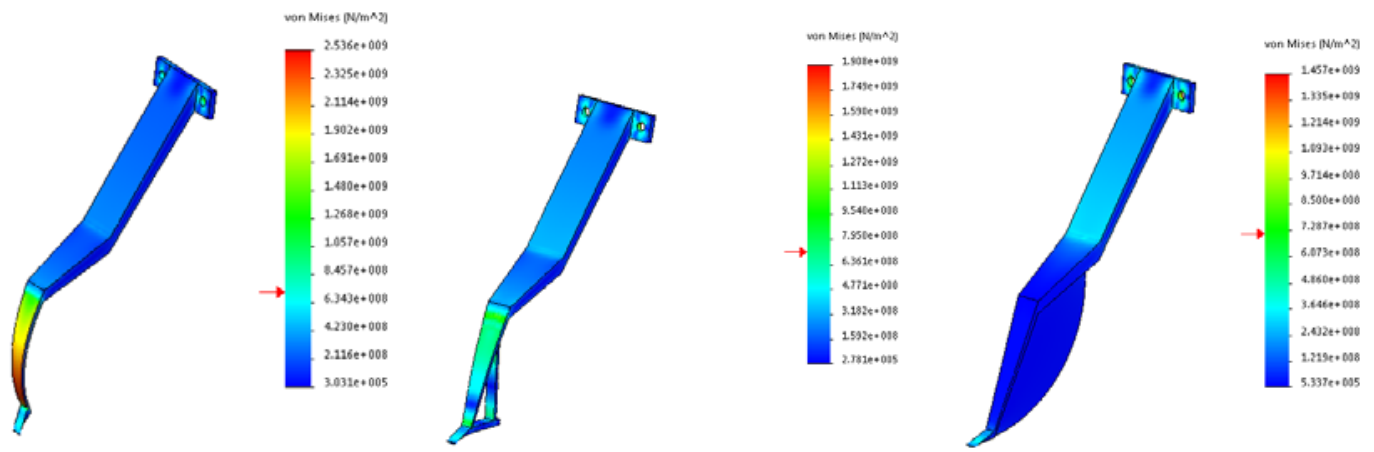

(a)Stress distribution cloud map 

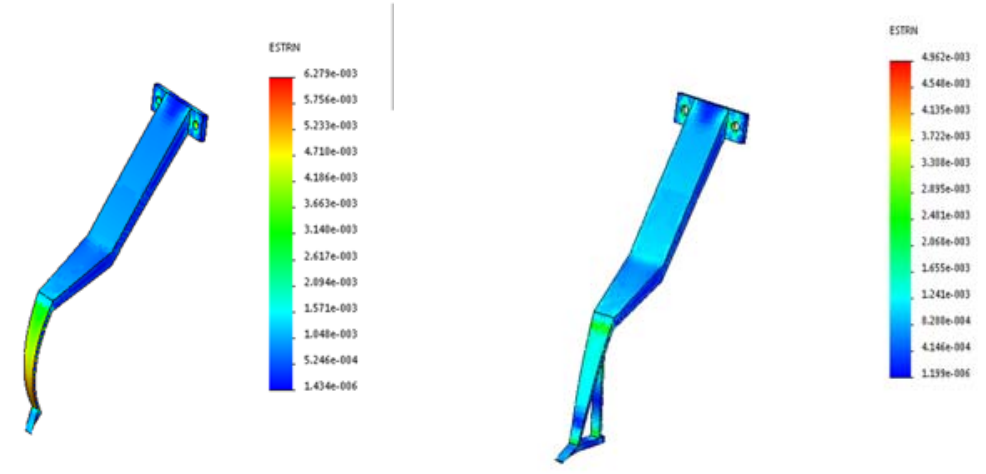

(b)Strain distribution cloud map

By figure A, In the work process of residual film recovery machine, When the film shovel is breaking the soil root stubble and turning the film, the tip of the tip of the bottom of the nozzle part of the most stress, and the outside of the position of the stress is more concentrated, that is, the maximum stress. The maximum stress is $2.536 \mathrm{e} 9 \mathrm{~N} / \mathrm{m} 2$ on the film-upturning shovel 1 . In the filmupturning shovel 2 and the film-upturning shovel 3, as the support plate is added, the distribution position of the larger stress is transferred to the fixed thread hole and the maximum stress is reduced, respectively, $1.981 \mathrm{e} 9 \mathrm{~N} / \mathrm{m} 2$ and $1.457 \mathrm{e} 9 \mathrm{n} / \mathrm{m} 2$, and the stress distribution is more dispersed and even at the tip of the bottom of the film-upturning shovel. The values are respectively $3.049 \mathrm{e} 8 \mathrm{~N} / \mathrm{m} 2$ and $2.350 \mathrm{e} 9 \mathrm{~N} / \mathrm{m} 2$. By Figure B, in the film-upturning shovel 1, there is a large strain at the junction of the lower part of the film-upturning shovel and the tip portion, and the deformation is obvious, the maximum strain is $5.156 \mathrm{e}-3$, and the strain quantity is $3.260 \mathrm{e}-4$ by the improved film-upturning shovel 2 and the film-upturning shovel 3 in this position. 10-4 and 6.353e-4, and the deformation is small, and the above two kinds of film-upturning shovel maximum strain appears in the threaded connection hole, the values are respectively $4.962 \mathrm{e}-3$ and $3.897 \mathrm{e}-3$. It can be obtained from the analysis conclusion that increasing the support plate in the lower part of the film shovel can effectively disperse the stress concentration, reduce the strain and the external structure deformation, and through the improvement, the stress and strain of the film-upturning shovel 2 and the film-upturning shovel 3 in the same position are significantly reduced than that of the film-upturning shovel 1 . The stress and strain of the film-upturning shovel 3 generation of the film shovel are most obvious. But the maximum stress and strain distribution of the film-upturning shovel 3 is in the threaded hole which is linked with the frame, in the actual work, it is likely to cause screw loose or even break, thus affecting the film-upturning shovel effect. In view of the above hidden trouble, the welding link is used in the actual processing, and the stress and strain of the improved film-upturning shovel at the link point are 6.054e-4 and 4.067e-7. As shown in (c).
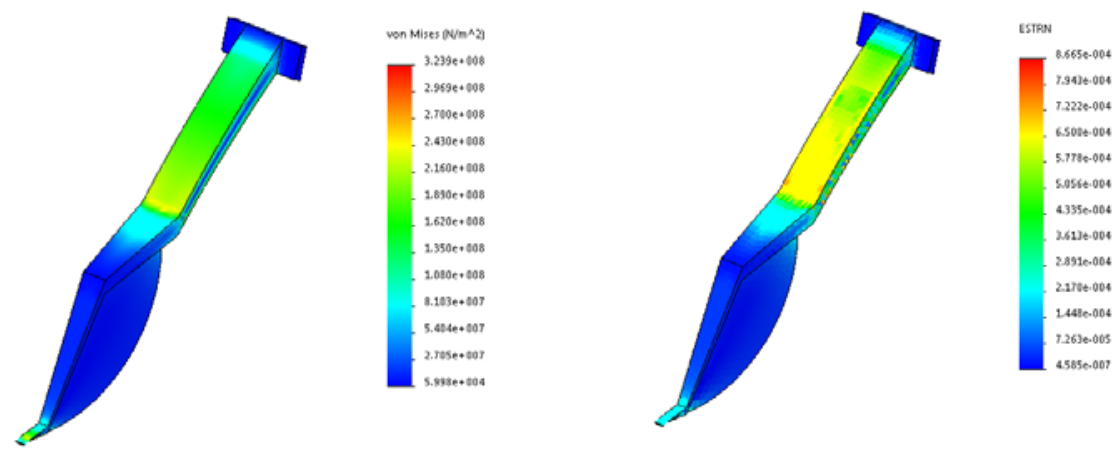

(c)The stress-strain distribution of the improved film-upturning shovel

Fig 3. The distribution of stress and strain of the film-upturning shovel

\subsubsection{Determination of the penetration angle $\alpha$ of a film-upturning shovel}

The size of the soil inclination of the film shovel will directly affect the resistance of the filmupturning shovel in the soil. The principle of determining the size of the Earth dip $\alpha$ is not to increase the resistance of the soil under the premise of the film-upturning shovel can be smoothly into the ground, the residual film and root stubble out, and loose the oil. 


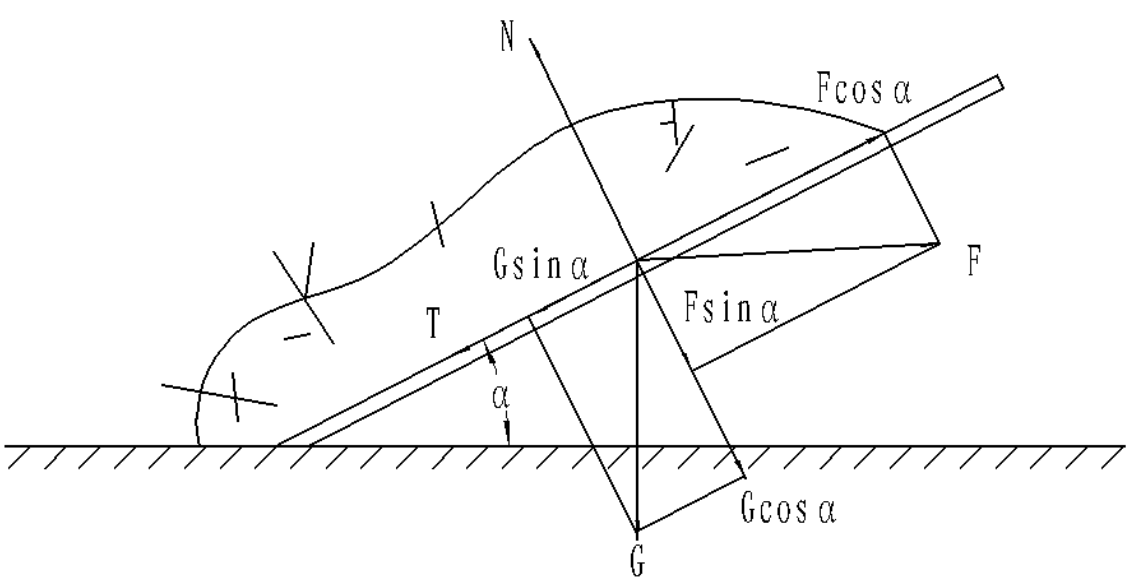

Fig 4. Sketch of the film-upturning shovel

The balance equation is listed by the force of the film-upturning shovel in Fig. 4 When the soil stubble and waste film are turned up.

$$
\left\{\begin{array}{l}
\mathrm{F} \cos \alpha-\mathrm{G} \sin \alpha-\mathrm{T}=0 \\
\mathrm{~N}-\mathrm{F} \sin \alpha-\mathrm{G} \cos \alpha=0
\end{array}\right.
$$

In the equation, F------ Working resistance of the film-upturning shovel

$\mathrm{N}$------ The reaction force of film and soil in the film-upturning shovel

G------ The gravity of the soil, stubble, and mulch

T------ Friction of the film-upturning shovel on the soil, stubble and film,

$\mathrm{T}=\mu^{\prime} \mathrm{N}, \mu^{\prime}$ is the friction coefficient between the membrane shovel and the soil.

From the equation we can get the ground angle of the film-upturning shovel:

$$
\alpha=\operatorname{arctg} \frac{F-\mu^{\prime} \mathrm{G}}{\mu^{\prime}+\mathrm{G}}
$$

If the value of $\alpha$ is greater than that obtained from the upper formula, then the soil stubble and residual film that the film-upturning shovel turns over will be redundant on the film-upturning shovel, thus increasing the resistance in the soil.

\subsection{Design Of the Film-Collecting Device}

\subsubsection{Design of The Film-Collecting Mechanism}

The mechanism is the key part of the machine, the specific design is as follows: camshaft welding on the rack, Rollers embedded in the convex roller lane installed in film-picking tooth shaft. When it working, the rollers move along the cam track in the slide, thus realizing the telescopic motion of the elastic tooth. As shown in Figure 5, figure 6.

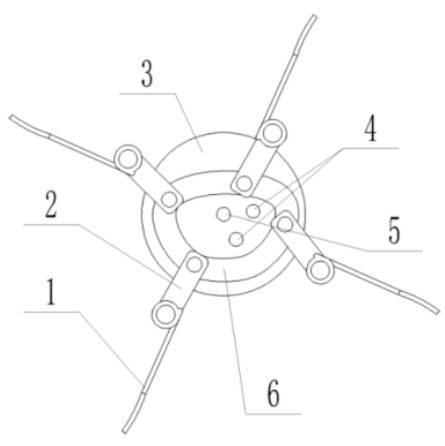

1. Film-picking tooth 2. Film-picking tooth shaft 3. Cam disk 4. Support shaft 5. Cam shaft 6. Cam slide

Fig 5. Camslide 
As shown in Fig. 6, the film-picking teeth are arranged on the Film-picking tooth shaft, with a interval of $100 \mathrm{~mm}$ for each set of film-picking teeth. The film-picking tooth extends out from the hole of the Film-picking roller. There is a pair of roller pairs between the film-picking shaft and the cam slide, and the roller diameter is $40 \mathrm{~mm}$, which is embedded in the cam slide. To prevent the roller jammed in the cam slide, there is a layer of oil film between the roller and slide surface. When the phenomenon of roller jammed, the film-picking teeth can continue to rotate, as the link between the roller shaft and the film-picking teeth shaft is articulated, so the roller will pass dead point and continue to move along the cam slide, this way can protect the rollers and prolongs the service life of the whole machine [8].

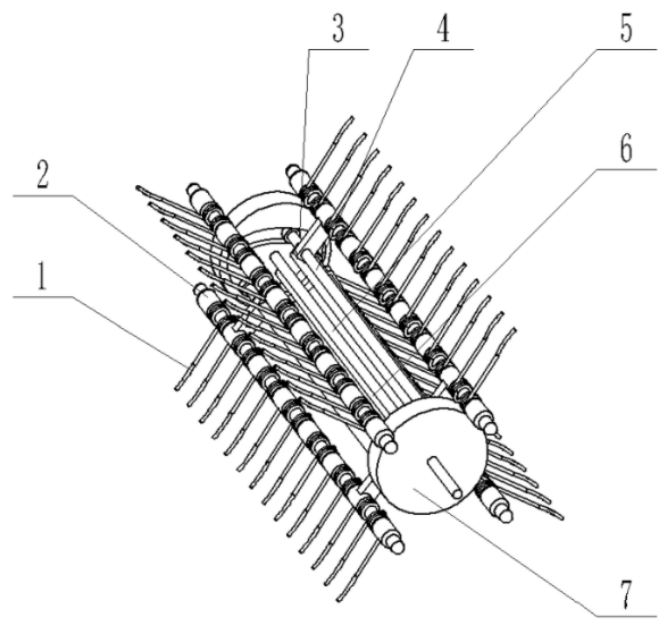

Fig 6. Diagram of the mechanism of collecting film

\subsubsection{Motion Analysis of the Film-Picking Teeth}

The film-picking elastic teeth are mounted in the film-collecting drum and rotate with the rotation of the drum, and the motion equation of the top of the film-picking projectile is as follows:

In the equation, $\mathrm{R}-------D r u m$ radius

$$
\left\{\begin{array}{l}
\mathrm{x}=\mathrm{R} \alpha-\frac{1}{\rho} \sin \alpha \\
\mathrm{y}=\mathrm{R}-1-\frac{1}{\rho}(\cos \alpha-\lambda)
\end{array}\right.
$$

Z------ The length of the z-bar

A------Drum rotation;

e------Eccentric distance;

Period: $\mathrm{T}=2 \pi \mathrm{R} ;$ Maximum point: $\mathrm{Ak}=[(2 \mathrm{~K}-1) \pi \mathrm{R}, 2 \mathrm{R}] ;$ Minimum point: $\mathrm{Bk}=$ $(2 \mathrm{k} \pi \mathrm{R},-2 \rho) ; \lambda=\mathrm{e} / \mathrm{R}[9]$.

The trajectory of the motion is shown in Figure 7:

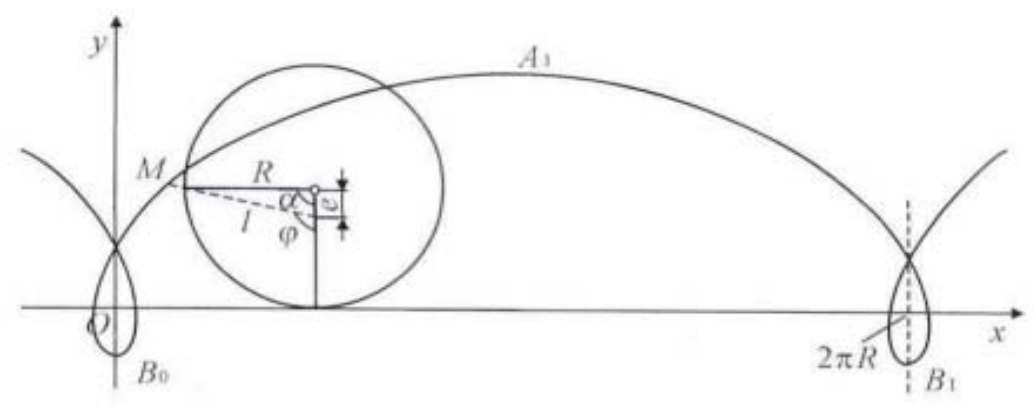

Fig7. The moving track of the top $\mathrm{M}$ of the telescopic rod 


\section{Conclusion}

Residual film recovery machine for whole plastic film mulching on double ridges can adapt to the agricultural requirements of whole plastic film mulching on double rides planting technology, It has characteristics of good adaptability, high reliability and easy to use, It also can effectively solve the problems brought by the waste film, suitable for Gansu and other arid area where using the planting technology of the whole plastic film mulching on double rides, and should be promoted. The successful development of the machine will save a lot of labor, ensure the quality of crops, increase production. It is of great significance to promote the development of regional agricultural mechanization, improve the ecological environment and promote the sustainable development of agriculture.

\section{Acknowledgements}

This work was financially supported by the Special Fund for Agroscientific Research in the Public Interest (No. 201503105), National Natural Science Foundation of China (Grant No. 51775115 and No. 51405086).

\section{References}

[1]. Li Laixiang, Liu Guangcai, Yang Qifeng, et al. Research and application development for the techniques of whole plastic-film mulching on double ridges and planting in catchment furrows in dry land [J]. Agricultural Research in the Arid Areas, 2009,27(01):115-116.

[2]. Ma Huiling. On the recovery of residual membrane [J]. Xinjiang Agricultural Mechanization, 2004, (04):13-14.

[3]. Zhang Jiaxi, Xie Jianhua, Xue Dangqin, et al. Development Status of Applying Plastic Film and the Residue Mulching Film Collecting Machine at Domestic and Overseas [J]. Journal of Agricultural Mechanization Research, 2013(12):236-240.

[4]. Hou Shulin, Hu Sanyuan, Kong Jianming, et al. Present Situation of Research on Plastic Film Residue Collector in China [J]. Transactions of the Chinese Society of Agricultural Engineering, 2002,18(03):186-189.

[5]. Lei Mingcheng, A Shicai, Meng Yangrong, et al. Design and experiment on 1FMJ-1000 plastic film collector [J]. Journal of Chinese Agricultural Mechanization, 2014,35(01):166-169.

[6]. Lü Zhaoqin, Zhang Lei, Zhang Guangling, et al. Design and test of chain guide rail-type plastic film collector [J]. Transactions of the Chinese Society of Agricultural Engineering, 2015,31 (18): 48-54.

[7]. Guo Xiaohuan, Dai Fei, Zhao Wuyun, et al. Design of the whole double furrow film picking baler machine [J]. Journal of Chinese Agricultural Mechanization, 2016,37 (09): 32-36+55.

[8]. Meng Hewei, Li Jinjiang, Wang Nengyong, et al. Comb Drum Design of Plastic Film Recycling Machine [J]. Journal of Agricultural Mechanization Research, 2012,34(03): 145-148.

[9]. Zhang Dongxing. Research and Design on Collector of Used Plastic Film on Farm Field [J]. Journal of China Agricultural University, 1999,4(06): 41-43. 